Article

\title{
Predicting Network Behavior Model of E-Learning Partner Program in PLS-SEM
}

\author{
Hsing-Yu Hou ${ }^{1, * \mathbb{C}}$, Yu-Lung Lo ${ }^{2}$ and Chin-Feng Lee ${ }^{2, *}$ (i) \\ 1 College of Information and Distribution Science, National Taichung University of Science and Technology, \\ Taichung 999079, Taiwan \\ 2 Department of Information Management, Chaoyang University of Technology, Taichung 999079, Taiwan; \\ yllo@cyut.edu.tw \\ * Correspondence: hsingyuhou@gm.nutc.edu.tw (H.-Y.H.); lcf@gm.cyut.edu.tw (C.-F.L.)
}

Received: 17 June 2020; Accepted: 2 July 2020; Published: 6 July 2020

\begin{abstract}
The Ministry of Education of Taiwan conducted an e-learning partner program to offer life-accompaniment and subject teaching to elementary and secondary students through a network platform with cooperation from university undergraduates. The aim of the e-learning partner program was to improve the motivation and interest of the children after learning at school. However, the outcome of this program stated that the retention rate of the undergraduates was low over three semesters in the case universities. Therefore, the training cost for the program was wasted each semester, and it was necessary to solve the problem and improve the situation. The evaluation of self-efficacy directly affects a person's motivation for the job. This research examined inner self-efficacy (teaching and counseling) and outer support (administration and equipment) that would contribute to and predict the success and the persistence of the e-learning partner program. There were 94 valid self-evaluation records in the 2019 academic year. ANOVA, post hoc, and partial least squares (PLS) analyses were conducted. The results showed that the year level, experience, and teacher education program background were significantly different in this study. The network behavior model was set up effectively to predict the retention from four scopes. A higher teaching self-efficacy would have better passion and innovation scores than the others. Using the suggestions for improvement, decreasing the gap between undergraduates' expectations and promoting sustainability in the e-learning partner program can be achieved.
\end{abstract}

Keywords: e-learning partner program; partial least squares structural equation modeling; retention; self-efficacy; teacher education program

\section{Introduction}

From 2016 to now, the Ministry of Education (MOE) of Taiwan conducted a digital application promotion plan in rural schools to improve digital skills, enrich digital competency (e-commerce and e-marketing), and promote enjoyment of mobile services as well as applications. The MOE e-learning partner program was one part of the plan [1]. Based on companionship, learning, and improving the motivation and interest of rural students, undergraduates used the internet to overcome barriers between urban and rural areas. The purpose was to promote equal learning opportunities for elementary and secondary students everywhere. In addition, the core values of this program included life accompanying life and living teaching living. There are two main targets: one is the learning of the children and the other is the teaching of the undergraduates. There was a total of ten weeks in one semester, with classes twice a week and two lessons each time (Chinese, English, or Mathematics). Each lesson lasted for $45 \mathrm{~min}$ with one-on-one online interaction. Regarding the partners, there were five primary and secondary schools that cooperated with the case university from 2017 until 
now. Many studies reported good performance of the e-learning partner program [2-5]. In the case university, the e-learning partner program has been promoted for four semesters. However, the outcome report of this program stated that the retention rate of the undergraduates was below $30 \%$ over three semesters [6]. At the beginning of each new semester, the program hosts had to invite lecturers to announce and impart the same knowledge and skills as those of the e-leaning partner program. The problem, as per program hosts, was considered an economic loss for the universities and talent loss for the team members of the program.

This present study aims to collect specific data of the undergraduates' inner characteristics and the outer environmental support to examine the significant factors that influence the persistence of the program. A sound and complete model can predict the user performance with technology by the analysis of personal learning behavior [7]. We use an advanced procedure to set up the predictive model of undergraduates' self-evaluation in an online e-learning partner program to improve the high talent turnover problem and decrease the cost of human-resource training.

The evaluation of self-efficacy will directly affect a person's motivation for the job. Yesilyurt et al. concluded that teacher self-efficacy, academic self-efficacy, and computer self-efficacy are important predictors of prospective teachers' attitudes toward applying computer-supported education [8]. Also, personalization features can match the user's attitude and behavior; therefore, they could enhance the user's performance and persistency with technology [9]. Some studies reported that there was a positive relationship between self-efficacy and positive attitude and predicted the attitude [10-12]. The variables of teaching efficacy and teaching satisfaction were also discussed $[13,14]$. In order to explore the results of the undergraduates' retention during one semester in the case university, collecting data on teaching, counseling, administration, and equipment evaluation was necessary.

Furthermore, the retention factor and designing of a questionnaire and its implementation during the mid-term and the end of the semester were important. For this reason, it is essential to detect which variables affect prospective undergraduates' attitudes toward applying for the e-learning partner program and to devise a predictive model in this program. In the e-learning partner program, there were 94 teaching undergraduates who completed the survey at the case university. When using a small sample, the partial least squares structural equation modeling (PLS-SEM) can be used to estimate the relationships between latent variables with several indicators $[15,16]$. Moreover, the method was applied in various research disciplines, such as marketing [17-19], management [20-23], finance [24-26], hospitality and tourism [27-29], information [30-32], social media [33,34], psychology [35], and science [36], and it was shown as capable of solving real-world problems. Many studies stated the predictive estimation capabilities of PLS-SEM [37-39]. Exploratory factor analyses of scales were analyzed via SPSS. For the confirmatory factor analyses of scales and the structural equation modeling, partial least squares (PLS) was used to predict the latent variable of retention in this program.

The aims of this study are (1) diagnosing the outcome of self-evaluation of undergraduates and determining which factors are significantly different, (2) evaluating the correlation among scores of self-evaluation, and (3) predicting the willingness of retention by carrying out PLS modelling. From the suggestions for improvement, a decrease in the gap of undergraduates' expectations and enhanced sustainability in the e-learning partner project can be achieved.

\section{Literature Review}

An interactive environment, administrative support, and perceived institutional resources influenced the learning completion intention of undergraduates [40]. Thus, teaching, counseling, administration, and equipment were included in our evaluation. Related to inner assessment, self-efficacy was described in many studies. The prediction method of PLS was also applied in many researches. 


\subsection{Self-Efficacy}

Self-efficacy, as developed by Bandura, indicated that people had confidence in a relevant area [41]. Effectiveness and self-efficacy of teaching were discussed in many studies [42-44]. Self-efficacy was effective in different aspects such as classroom management, teaching methods and techniques, and the use of computers and instructional tools [45]. In addition, it also affected students' learning performance. Sun found that environmental transformation, teaching innovation, class management, parent-teacher communication, teaching execution, and teaching evaluation influenced teaching quality [44]. $\mathrm{Xu}$ found that teacher self-efficacy was positively related to the teacher's perceived pressure, class management style, teaching-thinking style, commitment to teaching, willingness to carry out teaching innovation, and students' learning performance [46]. In this study, considering teaching self-efficacy and retention (passion and innovation), teaching indicators that included teaching preparation, teaching methods, and teaching attitude were adapted from Danielson, Keller, Pan et al. and the Ministry of Education [47-49].

Secondly, counseling self-efficacy is defined as a belief in the ability of individuals to perceive counseling cases effectively [50]. According to Larson and Daniels, studies on counseling self-efficacy are mostly conducted to understand the self-efficacy of counselors, including trainees or graduate students, school counselors, psychologists, or mental health-related personnel. Regarding the factors that affect the effectiveness of counseling, Larson and Daniels found that counselor characteristics, sexual orientation, age, training background, work experience, and other variables were important factors in predicting the self-efficacy of counselors in multiple studies. Case studies based on self-assessment by trained counselors have shown that those with higher self-efficacy in counseling have higher self-evaluations [51,52]. There are three sections related to counseling training: knowledge, skill, and belief [53]. In this study, counseling self-efficacy is divided into two parts. One is the attitude when tutoring the child (this includes understanding the child's position, accepting the child, trusting the child's ability, and respecting the child). The other is the positive perception of counseling knowledge and attitude.

Finally, the outer environment support and institutional resources, as well as administrative support and IT equipment were two important factors in the questionnaire that were designed by the MOE of Taiwan. The program hosts and assistants shared their experiences with the administrative support. With regard to the IT section, the platform of MOE, the e-learning interactive equipment (such as the software and the writing board) and the computers' network flow speed were employed to investigate the self-evaluation of the undergraduates during the semester at the case university.

\subsection{Retention}

According to [54], individual characteristics such as background and attitude affect students' dropout rates. Vianden and Barlow studied student loyalty with the assumption that students who develop positive attitudes toward their institutions are more likely to continue [55]. Furthermore, passion for long-term goals predicted retention among novice teachers [56,57]. Some researchers showed a strong link between talent retention and innovation [58,59]. Therefore, innovation and passion were two key factors related to retention in this paper. The control variables for the background used in this research were college, gender, subject, e-learning partner experiences, and teacher education program background.

\subsection{PLS}

PLS-SEM is a method used to estimate path models with latent variables and extend the principal component and canonical correlation analysis in statistics [60,61]. PLS can cope with smaller sample sizes than structural equation modeling (SEM) for the same effect size and model complexity, and it can more easily specify formative constructs [62-64]. In the formative model, it was necessary to assess the indicator weights and loads, and perform redundancy analyses. Chin provided redundancy 
analysis, in which each formatively specified construct correlated with its alternative measure [65]. The SmartPLS 3 software with a graphical user-interface was used to estimate the PLS-SEM models [66]. The first PLS software was published nearly ten years after LISREL III [67]. A relational predictive model is a research model that aims at determining the presence and the extent of the retention among the four self-evaluation variables.

\section{Methods}

In this context, the effect of the undergraduate retention toward using teaching, counseling, administration, and equipment evaluation on each other and their mutual relation are considered in this study.

\subsection{Samples and Procedure}

This research was conducted in two stages. The first was the factor analysis and the reliability and validity analyses of all items of the questionnaire to reduce the number of questions. ANOVA and post hoc analyses were conducted to determine the significant factors. The demographic features of the participants were gender, year level, college, teaching subjects, experience, and teacher education program background. Through ANOVA, we detected which of the background variables were significantly different in this study. Through post hoc analysis, multiple comparison analysis (over two levels) was explored. Furthermore, the PLS modelling in the final semester questionnaire was created to detect the correlation between retention (passion and innovation) and the four factors (teaching, counseling, administration, and IT equipment). Thereafter, it was extended to predict the future trend in this e-learning partner program to enhance the perseverance in the tutoring and teaching side.

The students completed the first questionnaire in the fifth week of the semester and the second one in the tenth week. In the 2019 academic year (from 21 October 2019 to 20 December 2019), 94 valid self-evaluation records were obtained twice. There were 10 weeks in total, with classes twice a week, covering two lessons each time (Chinese, English, or Mathematics). Each lesson lasted for $45 \mathrm{~min}$ with one-on-one online companion and learning. The ethical rule was stated as a declaration in the beginning of the questionnaire, and it was answered online. All the participants voluntarily attended the scale implementation process.

The demographic features of the participants were as follows. In terms of gender, $80.9 \%$ of the participants were female, and $19.1 \%$ were male participants. In terms of year level, $17 \%$ of the participants were in the first year, $38 \%$ in the second year, $24 \%$ in the third year, $13 \%$ in the fourth year, and $7 \%$ were masters students. In terms of college, $30 \%$ of the participants studied in the College of Humanities and Social Sciences, $6 \%$ in the College of Science and Engineering, $10 \%$ in the College of Design, 24\% in the College of Management, and 30\% in the College of Informatics. Considering the teaching subjects, $16 \%$ of the participants taught Chinese, $41 \%$ taught English, and $43 \%$ taught Mathematics. Considering experience, $76 \%$ were novices and $24 \%$ were experienced. Concerning teacher education program background, 34\% studied in the program, and 66\% did not.

\subsection{Measures and Variables}

The main variables of the teacher were college, gender, subject, e-learning partner experience, and teacher education program background. There were teaching, counseling, administrative, and equipment questions in the self-evaluation survey. With regard to retention, passion and innovation were two main variables. Students answered the questionnaire, using a five-point scale. The options were "strongly agree", "agree", "neutral", "disagree", and "strongly disagree". The scoring order was 5-1 points, respectively. The items on teaching, counseling, administration, and IT equipment are shown in Table 1. 
Table 1. Questionnaire items.

\begin{tabular}{|c|c|}
\hline Factor & Description \\
\hline \multicolumn{2}{|l|}{ Teaching } \\
\hline $\mathrm{T} 1$ & I can analyze students' prior knowledge and learning needs before teaching. \\
\hline $\mathrm{T} 2$ & $\begin{array}{l}\text { I can understand the physical and mental characteristics, learning experience, } \\
\text { learning interests, and learning environment of students before teaching. }\end{array}$ \\
\hline T3 & I can correctly grasp the teaching material of the subjects taught. \\
\hline $\mathrm{T} 4$ & I can choose textbooks and copies that meet the needs of school children. \\
\hline $\mathrm{T} 5$ & $\begin{array}{l}\text { I can specify the learning goals and show the impact of teaching materials on the } \\
\text { life or future of students. }\end{array}$ \\
\hline T6 & $\begin{array}{l}\text { I can provide new and old knowledge (such as information familiar to specific } \\
\text { children, daily life experience, etc.) related to school children. }\end{array}$ \\
\hline $\mathrm{T} 7$ & $\begin{array}{l}\text { I will create a teaching environment that respects harmony and fun and makes } \\
\text { my interaction with students effective. }\end{array}$ \\
\hline T8 & $\begin{array}{l}\text { I will effectively use a variety of teaching methods (such as questioning, } \\
\text { multimedia, games, etc.) to maintain the attention of students, creating challenges } \\
\text { and novelties. }\end{array}$ \\
\hline T9 & $\begin{array}{l}\text { I can use the teaching process from shallow to deep to provide students with a } \\
\text { chance to succeed. }\end{array}$ \\
\hline T10 & $\begin{array}{l}\text { I can provide the students challenging, moderate, and meaningful learning } \\
\text { lessons at the right time. }\end{array}$ \\
\hline T11 & $\begin{array}{l}\text { I can clarify to students the standards and implementation methods of learning } \\
\text { evaluation. }\end{array}$ \\
\hline $\mathrm{T} 12$ & $\begin{array}{l}\text { I can provide learners the opportunity (such as online real-time quizzes) to } \\
\text { demonstrate real results at the right time. }\end{array}$ \\
\hline $\mathrm{T} 13$ & $\begin{array}{l}\text { I will provide prompt and specific feedback (such as praise, drumming) and } \\
\text { suggestions at the appropriate time }\end{array}$ \\
\hline T14 & $\begin{array}{l}\text { I will use adaptive multiple evaluations such as oral expression and student } \\
\text { self-evaluation. }\end{array}$ \\
\hline T15 & $\begin{array}{l}\text { I have never used high-quality sound and light effects media (such as the use of } \\
\text { video games) to stimulate students to learn. }\end{array}$ \\
\hline T16 & $\begin{array}{l}\text { I am passionate about helping school children move towards positive } \\
\text { self-development. }\end{array}$ \\
\hline $\begin{array}{c}\text { T17 } \\
\text { Counseling }\end{array}$ & Counseling \\
\hline $\mathrm{C} 1$ & I believe that company is a meaningful thing. \\
\hline $\mathrm{C} 2$ & I think the opinions of every student should be respected. \\
\hline $\mathrm{C} 3$ & I am willing to accept the individual differences of school children in good faith. \\
\hline $\mathrm{C} 4$ & I believe that school children have the potential to overcome difficulties in life. \\
\hline C5 & $\begin{array}{l}\text { I agree that students have an autonomy without harming themselves and others } \\
\text { with their power of decision. }\end{array}$ \\
\hline \multicolumn{2}{|r|}{. } \\
\hline A1 & $\begin{array}{l}\text { The teacher with the class really helps to confirm the status of the elementary } \\
\text { school. }\end{array}$ \\
\hline A2 & The class teacher helps with network obstacles. \\
\hline A3 & $\begin{array}{l}\text { The teacher with the class really assists in the troubleshooting of hardware and } \\
\text { software equipment. }\end{array}$ \\
\hline A4 & The class teacher replied to the teaching diary. \\
\hline A5 & The class teacher counsels me on the teaching problems and tracks them. \\
\hline A6 & The education and training planned by our school team helped me. \\
\hline \multicolumn{2}{|r|}{ (2) } \\
\hline E1 & $\begin{array}{l}\text { The diary filling function meets the usage requirements (click on the screen after } \\
\text { the university is accompanied by the classroom). }\end{array}$ \\
\hline E2 & Textbook upload function meets the needs of use. \\
\hline E3 & JoinNet operation platform is stable. \\
\hline E4 & Computer classroom network connection is stable. \\
\hline E5 & Computer classroom hardware equipment is stable. \\
\hline \multicolumn{2}{|l|}{ Output } \\
\hline Innovation & My teaching activities can motivate students to learn. \\
\hline Passion & I often face my teaching work with enthusiasm and hope. \\
\hline
\end{tabular}

\subsection{The PLS Algorithm Procedure}

A participant group with smaller numbers was necessary for complex models in partial least square structural equation modelling. The bias-corrected and accelerated (BCa) bootstrapping procedure was used to assess the control variables' significance and interaction effects. The assessment of the significant control variables should use the $\mathrm{f}^{2}$ effect size to consider their relevance. In the beginning, 
the reliability and validity (first stage) were examined. Then, the degree of collinearity of the indicators and the significance and relevance of the indicator weights were analyzed. Finally, redundancy analysis was conducted.

\section{Results}

There were 94 valid self-evaluation records in the 2019 academic year (from 21 October 2019 to 20 December 2019). The post scores were significant $(p$-value $<0.05)$ and higher in T11, E5, and Innovation than those in the first survey. Teaching self-efficacy, administration, and equipment evaluations increased with time. Counseling self-efficacy decreased in the second stage; however, it was not significant.

\subsection{Factor Analysis}

According to the factor analysis used to reduce the items, there are four main functions in this study. The items that did not score higher than 0.5 in the loading weight would be deleted from the study. Initially, in the teaching items, the 17 items were classified into four main factors (TP $=$ teaching preparation, $\mathrm{TC}=$ teaching conference, $\mathrm{TA}=$ teaching attitude, and $\mathrm{TW}=$ teaching method). The factor of TP $=\{\mathrm{T} 1-\mathrm{T} 6, \mathrm{~T} 11-\mathrm{T} 12, \mathrm{~T} 15\}, \mathrm{TW}=\{\mathrm{T} 7-\mathrm{T} 10, \mathrm{~T} 13-\mathrm{T} 14\}, \mathrm{TA}=\mathrm{T} 16$, and $\mathrm{TC}=\mathrm{T} 17$. Moreover, $\mathrm{E} 1$ was deleted because the weight was lower than 0.5 . Through the principal analysis, a total of four functions were created in this study as shown in Table 2, and the significance was smaller than 0.05 in the KMO and Bartlett test. Related to the rotation sum of the squared loading, the cumulative percentage was 76.52 among the four main factors.

Table 2. Factor loading matrix.

\begin{tabular}{ccccc}
\hline & \multicolumn{3}{c}{ Factor } \\
\cline { 2 - 5 } & $\mathbf{A}$ & $\mathbf{C}$ & $\mathbf{T}$ & $\mathbf{E}$ \\
\hline A3 & 0.862 & & & \\
A5 & 0.766 & & & \\
A2 & 0.757 & & & \\
A6 & 0.741 & & & \\
A4 & 0.727 & & & \\
A1 & 0.712 & & & \\
C3 & & 0.867 & & \\
C2 & & 0.840 & & \\
C5 & & 0.738 & 0.804 & \\
C1 & & 0.708 & 0.788 & \\
C4 & & 0.693 & 0.786 & \\
TP & & & & 0.878 \\
TC & & & & 0.650 \\
TA & & & & \\
TW & & & & \\
E3 & & & & \\
E4 & & & & \\
E5 & & & & \\
E2 & & & & \\
\hline
\end{tabular}

After the factor analysis, we classified TP, TC, TA, and TW as Teaching; $\mathrm{C} 1-\mathrm{C} 5$ as Counseling; A1-A6 as Administration; and E2-E5 as Equipment. In the basic statistics in Figure 1, the score of Administration is the highest (mean $=4.761$ ) and the score of Teaching is the lowest (mean $=4.276$ ). It showed a high level of inner self-efficacy and outer support. Besides, the reliability and validity of the questionnaire were explored in Table 3. The Cronbach's alpha value of the scale was detected to be 0.886 for Teaching, 0.942 for Counseling, 0.912 for Administration, and 0.881 for Equipment. The Cronbach alphas of all four functions are greater than 0.8 . This indicated that the result had a good reliability. In convergence validity, the average variance extracted (AVE) was greater than 0.5 . In addition, all the 
correlation coefficients were better than 0.3 . In the discriminate validity, the coefficient was better than 0.7 . Furthermore, the four weights were higher than the others. This indicated good validity.

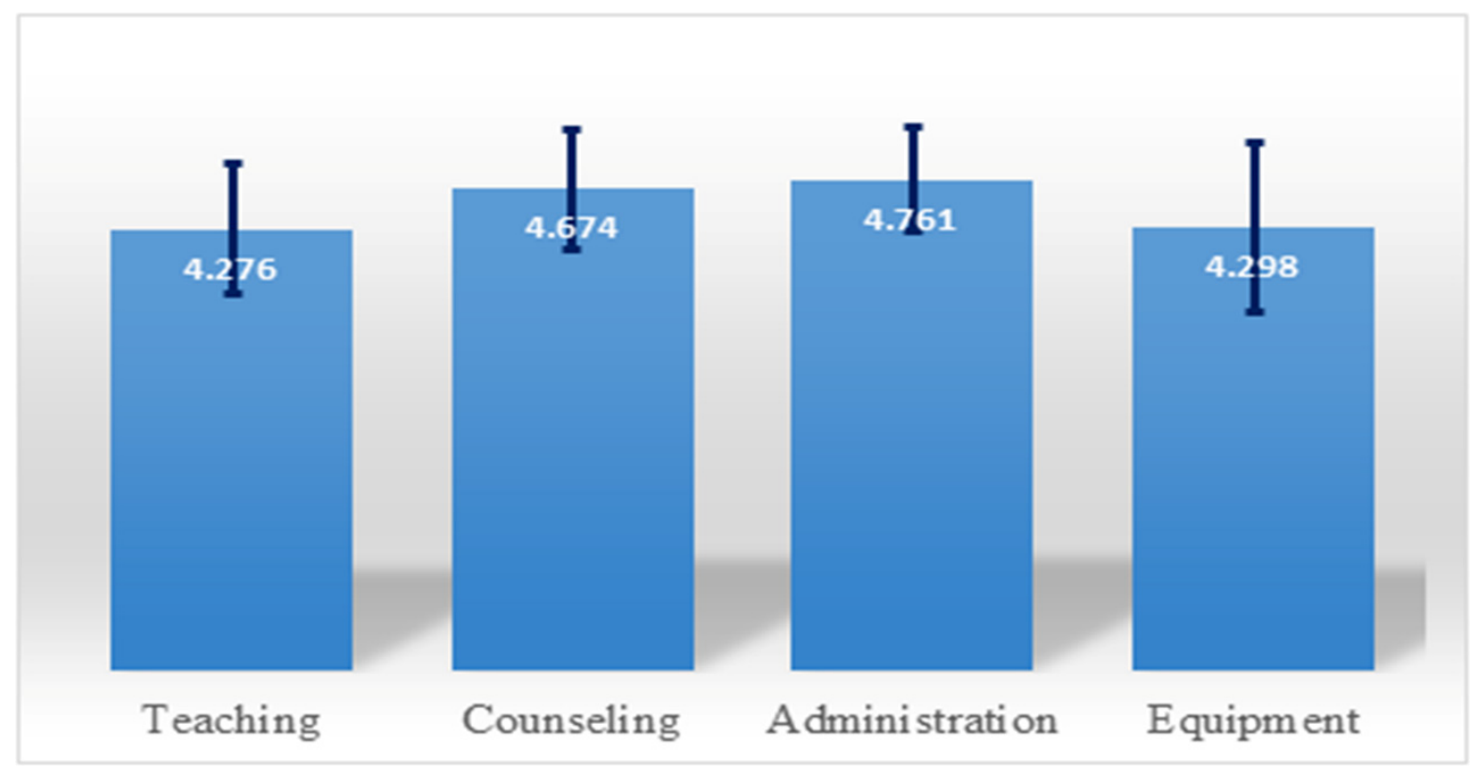

Figure 1. Basic statistics analysis: mean scores of the factors; the error bars denote standard deviation.

Table 3. Reliability and validity analyses.

\begin{tabular}{lcccccccc}
\hline Factor & Cronbach Alpha & AVE & Mean & SD & Teaching & Counseling & Administration & Equipment \\
\hline Teaching & 0.886 & 0.581 & 4.276 & 0.631 & 0.762 & 0.671 & 0.525 \\
Counseling & 0.942 & 0.600 & 4.674 & 0.581 & 0.671 & 0.775 & 0.671 \\
Administration & 0.912 & 0.606 & 4.761 & 0.510 & 0.525 & 0.671 & 0.778 \\
Equipment & 0.881 & 0.658 & 4.298 & 0.829 & 0.433 & 0.467 & 0.467 & 0.464 \\
\hline
\end{tabular}

Note: $\mathrm{AVE}=$ average variance extracted; $\mathrm{SD}=$ standard deviation.

\subsection{ANOVA and Post Hoc Analysis}

The demographic features of the participants were gender, year level, college, teaching subjects, experience, and teacher education program background. The freshman and sophomores were coded as 1 , the juniors and seniors were coded as 2, and the graduates were coded as 3. Through ANOVA and post hoc analysis (Scheffe method), year level, experience, and teacher education program background were significantly different in this study as demonstrated in Table 4 . The scores of third- and fourth-year participants were significantly higher than those of the first- and second-year undergraduates. In the e-learning partner program experience, the scores of the experienced participants was higher (4.47) than those of the novices (4.21) in self-efficacy of teaching. The participants who were enrolled in the teacher education program concurrently scored significantly higher in teaching (4.48 vs. 4.17) and counseling (4.81 vs. 4.60$)$ than those who were not enrolled in the teacher education program at the case university.

\subsection{PLS Analysis}

In this study, SmartPLS is used to process the original data from SPSS to CSV file. SmartPLS is advantageous for samples smaller than 100. There are a total of 94 participants in the survey, which is an appropriate sample size. Reasons for analyzing the data with this tool include small sample size, non-normal data, formative measures, focus on prediction, model complexity, exploratory research, and theory development. There are reflective, formative, and redundancy models in the PLS. From previous studies, a model that shows the effect level of the latent variables of teaching, counseling, administration, equipment, and retention on each other and their ratios to each other was put forward. 
In Figure 2, all the outer loadings are higher than 0.7. In collinearity statistics, the inner variance inflation factor was smaller than 10 . The four factors were not collinear in this research.

Table 4. ANOVA and post hoc analyses.

\begin{tabular}{cccccccc}
\hline \multicolumn{2}{c}{ Source of Variation } & SS & df & MS & F & $p$-Value & Post Hoc \\
\hline \multirow{2}{*}{ Teaching * Grade } & Between Group & 5.098 & 6 & 0.85 & 3.288 & 0.006 & $2>1$ \\
& Within Group & 22.484 & 87 & 0.258 & & 0.045 \\
\multirow{2}{*}{ Teaching * Experience } & Between Group & 1.187 & 1 & 1.187 & 4.138 & \\
& Within Group & 26.395 & 92 & 0.287 & & & \\
\hline \multirow{2}{*}{ Teaching * EduB } & Between Group & 2.117 & 1 & 2.117 & 7.647 & 0.007 \\
& Within Group & 25.466 & 92 & 0.277 & & & \\
\hline \multirow{2}{*}{ Counseling * EduB } & Between Group & 0.924 & 1 & 0.924 & 3.469 & 0.066 \\
& Within Group & 24.514 & 92 & 0.266 & & \\
\hline
\end{tabular}

Note: $p$-value is significantly smaller than $0.05, \mathrm{SS}$ = sum of squares; $\mathrm{df}=$ degree of freedom; $\mathrm{MS}=$ mean square; $\mathrm{F}=\mathrm{F}$ value.

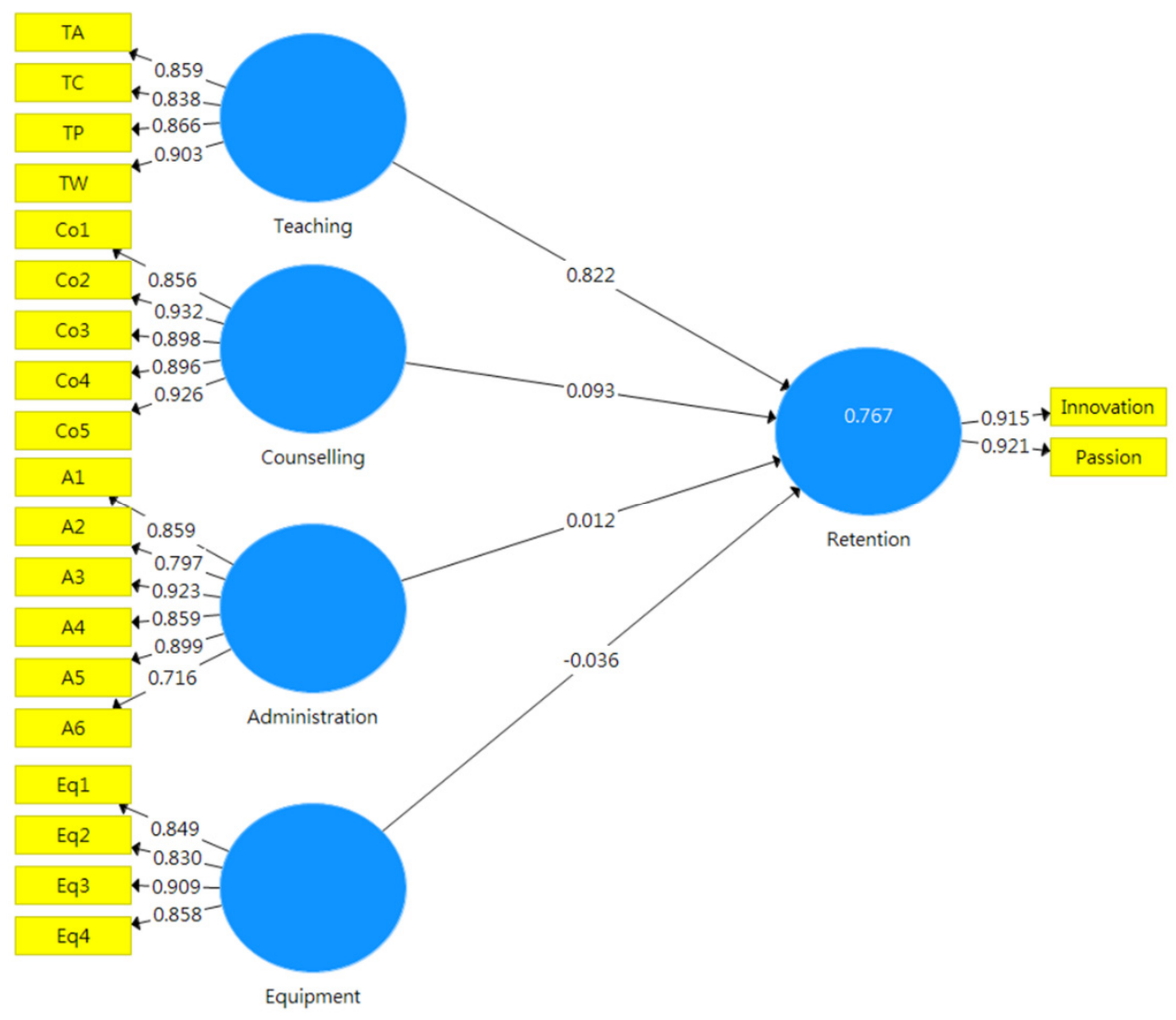

Figure 2. Partial least squares structure model (inner path coefficients and outer weights).

The path coefficients of the prediction model were positive in teaching, counseling, and administration; however, they were negative in equipment to the latent variable of retention. The model also presented innovation (0.915) and passion (0.921), which had positive path coefficients to retention.

In path coefficient analysis, the factor of teaching coefficient was higher than 0.7 , the total effect $p$-value was smaller than 0.05 , and $t>3.29$ (Table 5). This indicates that the formative construct in teaching can explain at least $50 \%$ of the variance of retention. 
Table 5. Path coefficients.

\begin{tabular}{lccccc}
\hline & $\begin{array}{c}\text { Original } \\
\text { Sample (O) }\end{array}$ & $\begin{array}{c}\text { Sample } \\
\text { Mean M) }\end{array}$ & $\begin{array}{c}\text { Standard } \\
\text { Deviation (STDEV) }\end{array}$ & $\begin{array}{c}\text { T Statistics } \\
(\mid \mathbf{O} / \text { STDEV|) }\end{array}$ & $p$ Values \\
\hline $\begin{array}{c}\text { Administration } \\
->\text { Retention }\end{array}$ & 0.012 & 0.017 & 0.077 & 0.150 & 0.881 \\
$\begin{array}{c}\text { Counseling -> } \\
\text { Retention }\end{array}$ & 0.093 & 0.077 & 0.097 & 0.956 & 0.339 \\
$\begin{array}{c}\text { Equipment }> \\
\text { Retention }\end{array}$ & -0.036 & -0.029 & 0.075 & 0.482 & 0.630 \\
$\begin{array}{c}\text { Teaching -> } \\
\text { Retention }\end{array}$ & 0.822 & 0.831 & 0.055 & 14.84 & $0.000^{*}$ \\
\hline
\end{tabular}

Note: * $p$-value is significantly smaller than 0.05 .

First, from Table 6 , all the composite reliability values are around $0.8-0.9$, supporting the internal consistency and reliability of the measures. Second, the values of convergence validity (AVE) were all higher than 0.5 , and the values of composite reliability (CR and Cronbach's alpha CA) were all higher than 0.7. In discriminate validity, the coefficient was smaller than 0.7. Although the teaching coefficient was 0.873 , it is smaller than 0.918 . Therefore, it is still in the reasonable range. Considering redundancy, if it is higher, the model is a good fit (goodness of fit $=$ Sqrt (redundancy)). This is similar to the model with blindfolding redundancy $>0$, indicating that the variable has a predictive relevance in the model. The construct cross redundancy $\mathrm{Q}^{2}(=1-\mathrm{SSE} / \mathrm{SSO})=0.63$ in retention was calculated, and it was a good fit in this model. Third, the $\mathrm{R}^{2}(0.767)$ was higher than 0.67 , indicating that it was valuable in real application. Fourth, the effect size $\mathrm{f}^{2}(0.79)$ was higher than 0.35 . This indicated that the outer variable (Teaching) significantly influenced the inner variable (Retention) and the $\mathrm{R}^{2}$ would increase. 
Table 6. Reliability and validity.

\begin{tabular}{|c|c|c|c|c|c|c|c|c|c|c|c|}
\hline & \multirow[b]{2}{*}{ AVE } & \multicolumn{5}{|c|}{ Convergence Validity (AVE) } & \multicolumn{5}{|c|}{ Discriminate Validity } \\
\hline & & $\begin{array}{l}\text { Composite } \\
\text { Reliability }\end{array}$ & R Square & $\begin{array}{c}\text { Cronbach's } \\
\text { Alpha }\end{array}$ & Communa & edundancy & A & $\mathrm{C}$ & E & $\mathbf{R}$ & $\mathbf{T}$ \\
\hline A & 0.714 & 0.937 & & 0.919 & 0.714 & & 0.845 & 0.687 & 0.509 & 0.497 & 0.536 \\
\hline $\mathrm{C}$ & 0.814 & 0.956 & & 0.943 & 0.814 & & 0.687 & 0.902 & 0.525 & 0.637 & 0.675 \\
\hline $\mathrm{E}$ & 0.742 & 0.920 & & 0.887 & 0.742 & & 0.509 & 0.525 & 0.862 & 0.421 & 0.490 \\
\hline $\mathrm{R}$ & 0.843 & 0.915 & 0.767 & 0.814 & 0.843 & 0.63 & 0.497 & 0.637 & 0.421 & 0.918 & 0.873 \\
\hline $\mathrm{T}$ & 0.751 & 0.923 & & 0.889 & 0.751 & & 0.536 & 0.675 & 0.49 & 0.873 & 0.867 \\
\hline
\end{tabular}

Note: $\mathrm{A}=$ Administration; $\mathrm{C}=$ Counseling; $\mathrm{E}=$ Equipment; $\mathrm{R}=$ Retention; $\mathrm{T}=$ Teaching. 


\section{Discussion}

\subsection{Self-Efficacy and Retention}

In the PLS model, the teaching self-efficacy significantly influenced the attitude of retention. Some studies discussed self-efficacy and retention. Gore found that a self-efficacious belief is an important predictor of the academic performances and achievement of university students [68]. The role of motivation, perceived effectiveness, and self-efficacy truly enhanced learner retention [69]. People with low self-efficacy are also timid against technological innovations and may display resistance against using computers as well $[70,71]$. In addition, the retention of teachers had positive effect on achievement of students [72,73]. Thus, a good model for predicting the willingness of instructors to persist was essential and necessary.

In the e-learning partner program, the grade year level, experience, and teacher education program background had a positive correlation with the teaching self-efficacy. Although the aim of this program was geared toward children, Chinese, English, and Mathematics were required in the interactive process. If institutions want to get maximum benefits on training, they must offer a supportive environment that can enhance self-efficacy and retention capabilities of their employees [74]. Without sufficient training in teaching, the undergraduates were not confident to face the students online. That was the reason willingness to persist in the e-learning program was low during each semester. Consequently, the learners in the e-learning partner program had to face new instructors and felt unstable in the learning process. This result was similar to a European survey, in which the younger generations were less willing to persist in the same organization and had lower organizational commitment [75]. Therefore, institutional managers needed to pay more attention to solve the problem of losing talents.

\subsection{Training Design}

The participants who were enrolled in the teacher education program had higher scores in teaching and counseling self-efficacy than those who were not enrolled. These results are similar to results of some studies that posited that participants in accelerated programs were older with more life and work experience and education, and the senior and experts often viewed them as being better critical thinkers, more inquisitive, and more confident [76-78]. The graduates from the accelerated e-learning partner programs had higher levels of confidence because they were older, and more mature. They have often already successfully completed a degree and had more life experience. For the hosts of the e-learning partner program reference, effective instruction in educational psychology, principles and methods of instruction, teaching methods, testing and evaluation, scientific research methods, management experience, and teaching practice may positively affect teaching self-efficacy of the novice undergraduates. Considering the teacher education program in the case university, the core competencies of the childhood teacher education program included educational knowledge and important educational issues [79]. The fundamental training design can include domain knowledge related to teaching knowledge, curriculum and instructional design skills, effective use of teaching strategies for effective teaching, appropriate methods for learning assessment, giving play to class management efficiency and creating a supportive learning environment, offering relevant counseling, educational professional responsibility, commitment to teacher professional growth and demonstration of collaboration and leadership. All curricula were related to teaching and counseling training, and this could improve the interactive confidence.

\section{Implications and Recommendations}

It was necessary for the online e-learning partner program to improve the high talent turnover and decrease the cost of human resource training. The purpose of this study was to analyze factors that could contribute to this. Although the participants in this research were limited to one case university, the model of predicting teachers' retention can be implemented at any university, especially novices in instruction in the world. If the institutional manager offered sufficient resources for teachers and 
learners, their interaction and communication could be stable and free of worry for a long-period in the e-learning process. The knowledge and subject area during each learning stage were consistent and systematic; therefore, the improvement of inner self-efficacy (teaching and counseling) and outer support could contribute to real or virtual classrooms anywhere Through workshops, professional seminars, instructors' communities, retention rewards, or apprenticeships held by the MOE in Taiwan, the e-learning partner program could be more successful and beneficial to the accompaniment of children in happiness and harmony.

\section{Conclusions}

The e-learning partners program was promoted for four semesters in the case university. However, the report of this program stated that the retention rate was a big problem. This study examined inner self-efficacy and outer support evaluation that would contribute to and predict the success and persistence of the e-learning partners' programs. The independent variables including year level, experience, and teacher education program background had significant impact on the self-evaluation survey in this study. Through PLS modeling, this study can deal with smaller sample sizes than SEM for the same effect size and model complexity and can more easily show formative constructs. After the path analysis, the teaching factor can better predict the network behavior model in this e-learning partner program. Therefore, this research could be of immense help to e-learning partner programs in improving their training strategies and it could be beneficial to the learning with technology. The model also has the potential to contribute to talent retention and to provide an optimal environment to support student learning and growth worldwide.

Author Contributions: All authors made significant contributions throughout this piece of research and agreed to submit the manuscript in the current form. H.-Y.H. made major contribution in terms of writing, designing questionnaires and analyzing data. H.-Y.H., Y.-L.L., C.-F.L. contributed in terms of conceptualization, and revising the manuscript. All authors have read and agreed to the published version of the manuscript.

Funding: This research was partially supported by the Ministry of Science and Technology, Taiwan, Republic of China under the Grant [MOST 108-2221-E-324-014].

Conflicts of Interest: The authors declare no conflict of interest.

\section{References}

1. The MOE E-Learning Partner Program. 2016. Available online: https://etutor.moe.gov.tw/zh/about/begin (accessed on 1 August 2016).

2. ChanLin, L.J.; Lin, H.Y.; Lu, T.H. Online after-school learning for bridging the digital divide. In Proceedings of the 12th IEEE International Conference on Advanced Learning Technologies (ICALT 2012), Rome, Italy, 4-6 July 2012; pp. 436-437.

3. Chen, Q.; Kao, T.C. Applying the flipped classroom instructional model to rural online tutoring program in upper elementary Mathematics. Contemp. Educ. Res. Q. 2019, 27, 1-37.

4. Elakovich, D.M. Does a Student's Use of Self-Regulation Change in the Flipped Classroom? Ph.D. Thesis, Montana State University, Bozeman, MT, USA, 2018.

5. Lo, C.K.; Hew, K.F. Using "first principles of instruction" to design secondary school mathematics flipped classroom: The findings of two exploratory studies. Educ. Technol. Soc. 2017, 20, 222-236.

6. Hou, H.Y.; Agrawal, S.; Lo, Y.L.; Lee, C.F. Applying Talent Quality-management System (TTQS) and Information Visualization to e-learning Partner Project. Adv. Intell. Syst. Comput. 2020, 1145, 207-217.

7. Qu, S.; Li, K.; Wu, B.; Zhang, S.; Wang, Y. Predicting student achievement based on temporal learning behavior in MOOCs. Appl. Sci. 2019, 9, 3793. [CrossRef]

8. Yesilyurt, E.; Ulas, A.H.; Akan, D. Teacher self-efficacy, academic self-efficacy, and computer self-efficacy as predictors of attitude toward applying computer-supported education. Comput. Hum. Behav. 2016, 64, 591-601. [CrossRef]

9. Oulasvirta, A.; Blom, J. Motivations in personalisation behavior. Interact. Comput. 2008, 20, 1-16. [CrossRef]

10. Li, L.K.Y. A study of the attitude, self-efficacy, effort and academic achievement of city u students towards research methods and statistics. Discov. Stud. E J. 2012, 1, 154-183. 
11. Ozkal, N. The Prediction of the positive attitudes towards the social studies courses according to the self-efficacy beliefs. Mersin Univ. J. Fac. Educ. 2013, 9, 399-408.

12. Tarkin, A.; Uzuntiryaki, E. Investigation of pre-service teachers' self-efficacy beliefs and attitudes toward teaching profession through canonical analysis. Elem. Educ. Online 2012, 11, 332-341.

13. Lin, C.H.; Li, W.U. A study of relationship between teaching efficacy and teaching satisfaction in the university students joining distance learning companion project. J. Cheng Shiu Univ. 2018, 31, 43-64.

14. Liu, W.T.; Lyau, N.M.; Lin, C.H. Construction of a remedial instruction effectiveness evaluation model for online after-school tutoring: An integrated perspective of students' learning motivation. J. Educ. Res. 2015, 49, 65-94.

15. Reinartz, W.; Haenlein, M.; Henseler, J. An empirical comparison of the efficacy of covariance-based and variance-based SEM. Int. J. Res. Mark. 2009, 26, 332-344. [CrossRef]

16. Wold, H. Soft modeling: The basic design and some extensions. In Systems under Indirect Observations: Part II; Joreskog, K.G., Wold, H., Eds.; North-Holland: Amsterdam, The Netherlands, 1982; pp. 1-54.

17. Hair, J.F.; Sarstedt, M.; Ringle, C.M.; Mena, J.A. An assessment of the use of partial least squares structural equation modeling in marketing research. J. Acad. Mark. Sci. 2012, 40, 414-433. [CrossRef]

18. Henseler, J.; Ringle, C.M.; Sinkovics, R.R. The use of partial least squares path modeling in international marketing. Adv. Int. Mark. 2009, 20, 277-320.

19. Richter, N.F.; Sinkovic, R.R.; Ringle, C.M.; Schlägel, C. A Critical Look at the Use of SEM in International Business Research. Int. Mark. Rev. 2016, 33, 376-404. [CrossRef]

20. Cepeda, C.G.; Cegarra, J.G. Tips to use partial least squares structural equation modelling (PLS-SEM) in knowledge management. J. Knowl. Manag. 2019, 23, 67-89. [CrossRef]

21. Lin, J.; Li, L.; Yan, Y.; Turel, O. Understanding Chinese consumer engagement in social commerce: The roles of social support and swift guanxi. Int. Res. 2018, 28, 2-22. [CrossRef]

22. Ringle, C.M.; Sarstedt, M.; Mitchell, R.; Gudergan, S.P. Partial least squares structural equation modeling in HRM research. Int. J. Hum. Res. Manag. 2018, 31, 1617-1643. [CrossRef]

23. Wu, Y.L.; Li, E.Y.; Chang, W.L. Nurturing user creative performance in social media networks: An integration of habit of use with social capital and information exchange theories. Int. Res. 2016, 26, 869-900. [CrossRef]

24. Lee, L.; Petter, S.; Fayard, D.; Robinson, S. On the use of partial least squares path modeling in accounting research. Int. J. Account. Inf. Sys. 2011, 12, 305-328. [CrossRef]

25. Nitzl, C. The use of partial least squares structural equation modelling (PLS-SEM) in management accounting research: Directions for future theory development. J. Account. Lit. 2016, 37, 19-35. [CrossRef]

26. Nitzl, C.; Chin, W.W. The Case of Partial Least Squares (PLS) Path Modeling in Managerial Accounting. J. Manag. Control 2017, 28, 137-156. [CrossRef]

27. Ali, F.; Rasoolimanesh, S.M.; Sarstedt, M.; Ringle, C.M.; Ryu, K. An assessment of the use of partial least squares structural equation modeling (PLS-SEM) in hospitality research. Int. J. Contemp. Hosp. Manag. 2018, 30, 514-538. [CrossRef]

28. Do Valle, P.O.; Assaker, G. Using partial least squares structural equation modeling in tourism research: A review of past research and recommendations for future applications. J. Travel Res. 2016, 55, 695-708. [CrossRef]

29. Usakli, A.; Kucukergin, K.G. Using partial least squares structural equation modeling in hospitality and tourism: Do researchers follow practical guidelines? Int. J. Contemp. Hosp. Manag. 2018, 30, 3462-3512. [CrossRef]

30. Hair, J.F.; Hollingsworth, C.L.; Randolph, A.B.; Chong, A.Y.L. An updated and expanded assessment of PLS-SEM in information systems research. Ind. Manag. Data Sys. 2017, 117, 442-458. [CrossRef]

31. Khan, G.F.; Sarstedt, M.; Shiau, W.L.; Hair, J.F.; Ringle, C.M.; Fritze, M.P. Methodological research on partial least squares structural equation modeling (PLS-SEM): An analysis based on social network approaches. Int. Res. 2019, 29, 407-429. [CrossRef]

32. Ringle, C.M.; Sarstedt, M.; Straub, D.W. Editor's comments: A critical look at the use of PLS-SEM in MIS quarterly. MIS Q. 2012, 36, 3-14. [CrossRef]

33. Cao, X.; Guo, X.; Vogel, D.; Zhang, X. Exploring the influence of social media on employee work performance. Int. Res. 2016, 26, 529-545. [CrossRef]

34. Kim, B.; Min, J. The distinct roles of dedication-based and constraint-based mechanisms in social networking sites. Int. Res. 2015, 25, 30-51. [CrossRef] 
35. Willaby, H.W.; Costa, D.S.J.; Burns, B.D.; MacCann, C.; Roberts, R.D. Testing complex models with small sample sizes: A historical overview and empirical demonstration of what Partial Least Squares (PLS) can offer differential psychology. Pers. Individ. Differ. 2015, 84, 73-78. [CrossRef]

36. Avkiran, N.K. An in-depth discussion and illustration of partial least squares structural equation modeling in health care. Health Care Manag. Sci. 2018, 1, 401-408. [CrossRef] [PubMed]

37. Evermann, J.; Tate, M. Assessing the predictive performance of structural equation model estimators. J. Bus. Res. 2016, 69, 4565-4582. [CrossRef]

38. Schlittgen, R.; Ringle, C.M.; Sarstedt, M.; Becker, J.-M. Segmentation of PLS path models by iterative reweighted regressions. J. Bus. Res. 2016, 69, 4583-4592. [CrossRef]

39. Shmueli, G.; Ray, S.; Estrada, J.M.V.; Chatla, S.B. The elephant in the room: Predictive performance of PLS models. J. Bus. Res. 2016, 69, 4552-4564. [CrossRef]

40. Darrin, T. Factors that Influence College Completion Intention of Undergraduate Students. Asia Pac. Educ. Res. 2014, 23, 225-235.

41. Bandura, A. Self-Efficacy: The Exercise of Control; Freeman: New York, NY, USA, 1997.

42. Sun, Z.L. Elementary school teachers' self-efficacy and class management orientation. J. Chengchi Univ. 1996, 72, 121-150.

43. Sun, Z.L. The relationship between teachers' self-efficacy and teaching behavior: An analysis of the essence orientation. J. Nat. Taipei Norm. Univ. 2001, 14, 109-140.

44. Sun, Z.L. The concept and measurement of teacher self-efficacy. J. Educ. Psychol. 2003, 34, 139-156.

45. Gurol, A.; Altunbaş, S.; ve Karaaslan, N. Öğretmen adaylarının öz yeterlik inançları ve epistemolojik inançları üzerine bir çalışma. E J. New World Sci. Acad. 2010, 5, 1395-1404.

46. Xu, Y.L. The Orientation and Limitation of Teachers 'Efficacy Research: An Exploration towards Changing Teachers' Efficacy. J. Educ. Res. Tzu Chi Univ. 2006, 2, 109-137.

47. Danielson, C. Enhancing Professional Practice: A Framework for Teaching, 2nd ed.; ASCD: Alexandria, VA, USA, 2007.

48. Keller, J.M. Development and use of the ARCS model of instructional design. J. Instr. Dev. 1987, 10, 2-10. [CrossRef]

49. Pan, H.L.; Wang, L.Y.; Jian, M.F.; Sun, Z.L.; Zhang, S.Z.; Zhang, X.X.; Chen, S.H.; Chen, S.M.; Cai, B.R. The development of national primary and secondary school teachers' teaching professional ability indicators. Educ. Res. Inf. 2004, 12, 129-168.

50. Larson, L.M.; Daniels, J.A. Review of counseling self-efficacy literature. Couns. Psychol. 1998, 26, 179-218. [CrossRef]

51. Larson, L.M.; Suzuki, L.A.; Gillespie, K.N.; Potenza, M.T.; Bechtel, M.A.; Toulouse, A.L. Development and validation of the counseling self-estimate inventory. J. Couns. Psychol. 1992, 39, 105-120. [CrossRef]

52. Urbani, S.; Smith, M.R.; Maddux, C.D.; Smaby, M.H.; Torres-Rivera, E.; Crews, J. Skills-based training and counseling self-efficacy. Couns. Educ. Superv. 2002, 42, 92-106. [CrossRef]

53. Coles, K.E.; Owens, S.J.; Serrano, J.V.; Slavee, J.; Evans, W.S. From consultation to student outcomes: The role of teacher knowledge, skills, and beliefs in increasing integrity in classroom management strategies. Sch. Ment. Health 2015, 7, 34-48. [CrossRef]

54. Rumberger, R.W. Dropping Out: Why Students Drop Out of High School and What Can Be Done about It; Harvard University Press: Cambridge, MA, USA, 2011.

55. Vianden, J.; Barlow, P.J. Showing the love: Predictors of student loyalty to undergraduate institutions. J. Stud. Aff. Res. Pract. 2014, 51, 16-29. [CrossRef]

56. Ng, P.T.; Lim, K.M.; Low, E.L.; Hui, C. Provision of early field experiences for teacher candidates in Singapore and how it can contribute to teacher resilience and retention. Teach. Dev. 2018, 22, 632-650. [CrossRef]

57. Robertson-Kraft, C.; Duckworth, A. True Grit: Trait-Level Perseverance and Passion for Long-Term Goals Predicts Effectiveness and Retention among Novice Teachers. Teach. Coll. Rec. 2014, 116, 1-40.

58. Kundu, S.C.; Gahlawat, N. Effects of employee retention practices on perceived firm and innovation performance. Int. J. Innov. Learn. 2016, 19, 25-43. [CrossRef]

59. Miguel, I. Innovation, Talent Attraction and Retention. 2012. Available online: http://hdl.handle.net/10437/3394 (accessed on 10 July 2012).

60. Henseler, J.; Dijkstra, T.K.; Sarstedt, M.; Ringle, C.M.; Diamantopoulos, A.; Straub, D.W.; Ketchen, D.J.; Hair, J.F.; Hult, G.T.M.; Calantone, R.J. Common beliefs and reality about partial least squares: Comments on Rönkkö and Evermann (2013). Organ. Res. Methods 2014, 17, 182-209. [CrossRef] 
61. Sarstedt, M.; Hair, J.F.; Ringle, C.M.; Thiele, K.O.; Gudergan, S.P. Estimation issues with PLS and CBSEM: Where the bias lies! J. Bus. Res. 2016, 69, 3998-4010. [CrossRef]

62. Jackson, D.L. Revisiting sample size and number of parameter estimates: Some support for the n:q hypothesis. Struct. Equat. Model. Multidiscip. J. 2003, 10, 128-141. [CrossRef]

63. Diamantopoulos, A.; Riefler, P.; Roth, K.P. Advancing formative measurement models. J. Bus. Res. 2008, 61, 1203-1218. [CrossRef]

64. MacKenzie, S.B.; Podsakoff, P.M.; Podsakoff, N.P. Construct Measurement and Validation Procedures in MIS and Behavioral Research: Integrating New and Existing Techniques. MIS Q. 2011, 5, 293-334. [CrossRef]

65. Chin, W.W. The partial least squares approach for structural equation modelling. In Modern Methods for Business Research; Marcoulides, G.A., Ed.; Lawrence Erlbaum Associates: Hillsdale, NJ, USA, 1998.

66. Ringle, C.M.; Wende, S.; Becker, J.M. SmartPLS. 3; SmartPLS GmbH: Bönningstedt, Germany, 2015.

67. Lohmöller, J.B. Latent Variable Path Modeling with Partial Least Squares; Physica: Heidelberg, Germany, 1989.

68. Gore, P.A. Academic self-efficacy as a predictor of college outcomes: Two incremental validity studies. J. Career Assess. 2006, 14, 92-115. [CrossRef]

69. Sujatha, R.; Kavitha, D. Learner retention in MOOC environment: Analyzing the role of motivation, self-efficacy and perceived effectiveness. Int. J. Educ. Dev. Using Inf. Commun. Technol. 2018, 14, 62-74.

70. Chou, C.M.; Hsiao, C.H.; Shen, H.C.; Chen, S.G. Analysis of factors in technological and vocational school teachers' perceived organizational innovative climate and continuous use of e-teaching: Using computer self-efficacy as an intervening variable. Turkish Online J. Educ. Technol. 2010, 9, 35-48.

71. Holden, H.; Rada, R. Understanding the influence of perceived usability and technology self-efficacy on teachers' technology acceptance. J. Res. Technol. Educ. 2011, 43, 343-367. [CrossRef]

72. Shifrer, D.; Turley, R.L.; Heard, H. Do Teacher financial awards improve teacher retention and student achievement in an urban disadvantaged school district? Am. Educ. Res. J. 2017, 54, 1117-1153. [CrossRef]

73. Pedota, P.J. How can student success support teacher self-efficacy and retention? Clgh. J. Educ. Strat. Issues Ideas 2015, 88, 54-61. [CrossRef]

74. Iqbal, K.; Dastgeer, G. Impact of self-efficacy and retention on transfer of training: The mediating role of motivation to transfer. J. Manag. Dev. 2017, 36, 1270-1282. [CrossRef]

75. D'Amato, A.; Herzfeldt, R.; Macky, K. Learning orientation, organizational commitment and talent retention across generations: A study of European managers. J. Manag. Psychol. 2008, 23, 929-953. [CrossRef]

76. Cangelosi, P.R. Voices of graduates from second-degree baccalaureate nursing programs. J. Prof. Nurs. 2007, 23, 91-97. [CrossRef] [PubMed]

77. Lofmark, A.; Smide, B.; Wikblad, K. Competence of newly-graduated nurses-a comparison of the perceptions of qualified nurses and students. J. Adv. Nurs. 2006, 3, 721-728. [CrossRef]

78. Suliman, W.A. Critical thinking and learning styles of students in conventional and accelerated programmes. Int. Nurs. Rev. 2006, 3, 73-79. [CrossRef]

79. The Core Competencies of the Childhood Teacher Education Program. 2016. Available online: http: //edu.cyut.edu.tw/p/404-1047-10197.php (accessed on 1 August 2016).

(C) 2020 by the authors. Licensee MDPI, Basel, Switzerland. This article is an open access article distributed under the terms and conditions of the Creative Commons Attribution (CC BY) license (http://creativecommons.org/licenses/by/4.0/). 